\title{
Coalbed methane-produced water quality and its management options in Raniganj Basin, West Bengal, India
}

\author{
Vinod Atmaram Mendhe ${ }^{1}$ Subhashree Mishra ${ }^{1}$ Atul Kumar Varma ${ }^{1}$. \\ Awanindra Pratap Singh ${ }^{1}$
}

Received: 20 November 2014 / Accepted: 25 August 2015/Published online: 9 September 2015

(C) The Author(s) 2015. This article is published with open access at Springerlink.com

\begin{abstract}
Coalbed methane (CBM) recovery is associated with production of large quantity of groundwater. The coal seams are depressurized by pumping of water for regular and consistent gas production. Usually, CBM operators need to pump $>10 \mathrm{~m}^{3}$ of water per day from one well, which depends on the aquifer characteristics, drainage and recharge pattern. In India, 32 CBM blocks have been awarded for exploration and production, out of which six blocks are commercially producing methane gas at 0.5 million metric standard cubic feet per day. Large amount of water is being produced from CBM producing blocks, but no specific information or data are available for geochemical properties of CBM-produced water and its suitable disposal or utilization options for better management. CBM operators are in infancy and searching for the suitable solutions for optimal management of produced water. CBM- and mine-produced water needs to be handled considering its physical and geochemical assessment, because it may have environmental as well as long-term impact on aquifer. Investigations were carried out to evaluate geochemical and hydrogeological conditions of CBM blocks in Raniganj Basin. Totally, 15 water samples from CBM well head and nine water samples from mine disposal head were collected from Raniganj Basin. The chemical signature of produced water reveals high sodium and bicarbonate concentrations
\end{abstract}

Vinod Atmaram Mendhe vamendhe@gmail.com

1 Central Institute of Mining and Fuel Research, Dhanbad, Jharkhand, India with low calcium and magnesium, and very low sulphate in CBM water. It is comprehend that $\mathrm{CBM}$ water is mainly of $\mathrm{Na}-\mathrm{HCO}_{3}$ type and coal mine water is of $\mathrm{Ca}-$ $\mathrm{Mg}-\mathrm{SO}_{4}$ and $\mathrm{HCO}_{3}-\mathrm{Cl}-\mathrm{SO}_{4}$ type. The comparative studies are also carried out for CBM- and mine-produced water considering the geochemical properties, aquifer type, depth of occurrence and lithological formations. Suitable options like impounding, reverse osmosis, irrigation and industrial use after prerequisite treatments are suggested. However, use of this huge volume of CBMand mine-produced water for irrigation or other beneficial purposes may require careful management based on water $\mathrm{pH}, \mathrm{EC}, \mathrm{TDS}$, alkalinity, bicarbonate, sodium, fluoride, metals content and SAR values.

Keywords CBM and coal mine water - Quality · Geochemical · Utilization and disposal options
Abbreviations
TDS Total dissolved solids
EC Electrical conductivity
SAR Sodium adsorption ratio
NTU Nephelometric turbidity units

\section{Introduction}

In India, CBM recovery is increasing day-by-day and expected to rise from current 0.5 to $7 \mathrm{mmscmd}$ by 2020 . The commercial methane production in India has been started since 2007, first in Raniganj Coalfield by GEECL and consequently by Essar and ONGC. Production of CBM is associated with pumping of large quantity of aquifer 
water to reduce hydrostatic pressure existing on coal seams. Produced water quality and quantity vary widely, and it is necessary to manage through some combinations of treatment, storage, disposal and use. Unlike conventional gas reservoirs, coal is both the reservoir rock and the source rock for methane. CBM wells, in comparison with conventional oil and gas wells, produce large volume of water early in their life, and the water volume declines over time (Khatib and Verbeek 2003). Usually, CBM-produced water is discharged into associated unlined holding ponds (Reddy et al. 2003). Management of CBM-produced water is associated with challenges, and it is also very expensive for operators. Understanding about produced water characteristics can help in increasing the production and also knowledge of its chemical constituents; operators can determine the proper application of scale inhibitors and well treatment chemicals as well as identify potential wellbore or reservoir problem areas (Breit et al. 1998). The geochemical properties of CBM-produced water vary with the original depositional environment, depth of burial and coal type, and it vary significantly across production areas (Jackson and Myers 2002). CBM-produced water can be beneficially used, but the presence of some of the chemical parameters and their concentrations may limit the use of these waters in certain areas (Shramko et al. 2009). The suitability of CBM-produced water for agricultural purposes generally irrigation or stock watering, will depend not only on the quality of the produced water but also on the conditions of the receiving areas (ALL 2003).

This paper presents the basic information on various physical and geochemical aspects of CBM- and coal mineproduced water. It also focuses on, how it is to be managed and regulated using suitable suggested options under environmental settings at Raniganj Coalfield.

\section{Process of CBM production}

Methane occurs in adsorbed state within the micropores of coal; in order to recover it, the CBM reservoirs are depressurized by pumping of water (Mendhe et al. 2010). Typically, water must be produced continuously from coal seams to decrease the reservoir pressure and release the gas (Dart Energy International 2013). Once the pressure in the cleat/fracture system is lowered by water production to the "critical desorption pressure", gas gets desorbs from the coal matrix. The CBM reservoirs are of low pressure and initially produce large quantity of water to reach desired

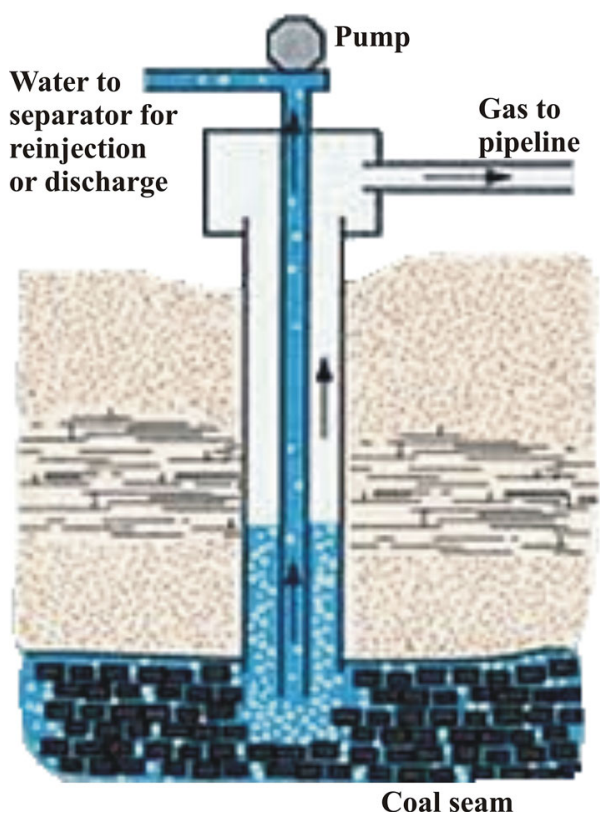

Fig. 1 CBM extraction process

rate of gas production. The produced water needs to be managed considering its geochemical properties, surface drainage pattern and low-cost methods for its treatment and use, because the cost of treatment and disposal of the produced water may be a critical factor in the economics of a coalbed methane project. The schematic of CBM production process and curve is given in Figs. 1 and 2, respectively.

\section{Study area}

The Raniganj Coalfield is the easternmost depository within the Damodar Valley of Gondwana Basin (Ghosh 2002). It is bounded by latitudes $23^{\circ} 03^{\prime}$ and $23^{\circ} 51^{\prime} \mathrm{N}$ and longitudes $86^{\circ} 42^{\prime}$ and $87^{\circ} 28^{\prime} \mathrm{E}$ (Murthy et al. 2010). Raniganj Formation of the Upper Permian age bearing thick coal seams is the most prolific for CBM reserve (Datta 2003; DGH 2006). The gas-bearing coal seams laterally varying in thickness and depth range from 1.6 to 22 and 26 to $1250 \mathrm{~m}$, respectively. There are three CBM blocks that have been awarded for exploration and production development: GEECL_-south block, ONGCnorth-central block and Essar-northeast block.

The generalized stratigraphic succession of Raniganj Coalfield is given below (after Gee 1932). 
Fig. 2 Typical production curve of a CBM reservoir

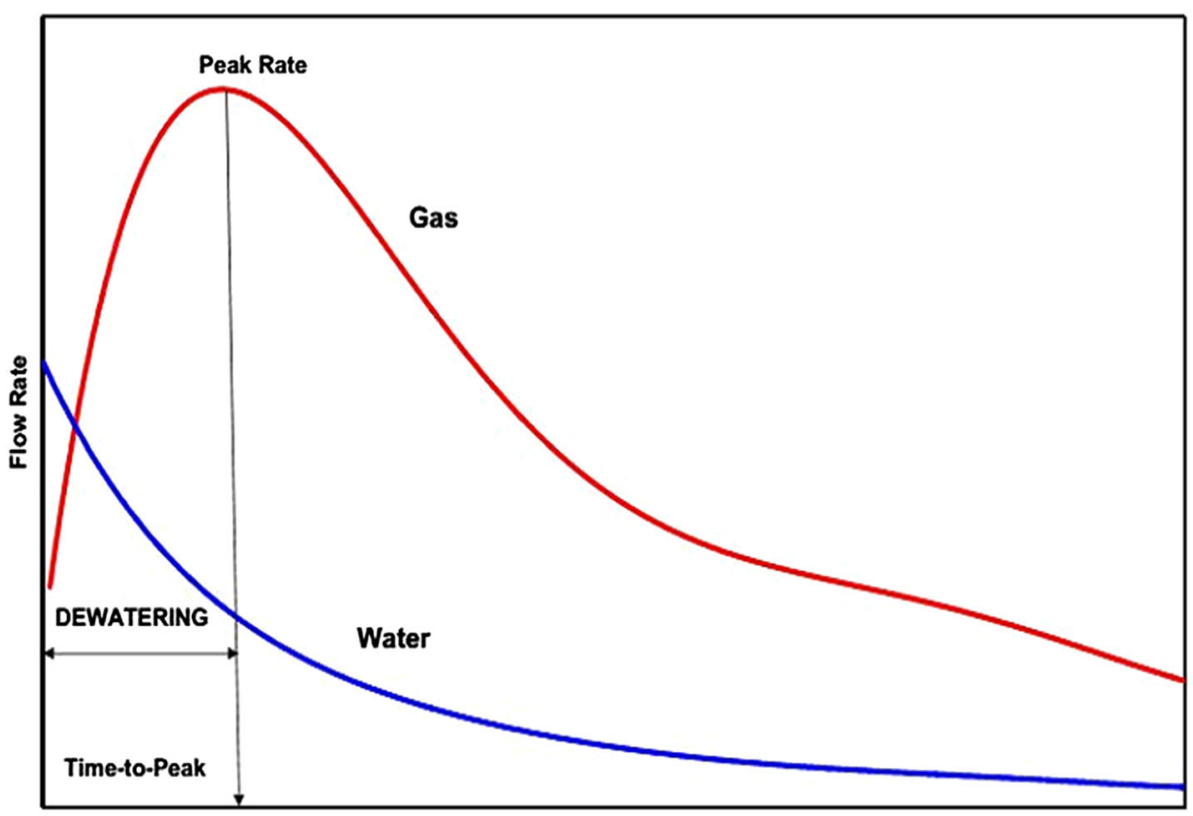

Time (Year)

\begin{tabular}{|c|c|c|c|}
\hline Age & Formation & Thickness (m) & Lithology \\
\hline Recent and quaternary & & & Alluvium and sandy soil, lateritic gravel and clay \\
\hline \multicolumn{4}{|l|}{ Unconformity } \\
\hline Jurassic & Igneous intru & & Dolerite dykes, mica peridotite dykes and sills \\
\hline Upper Triassic & Supra Panchet & 300 & Coarse red-yellow-grey sst, quartzite, conglomerate and shale bands \\
\hline Lower Triassic & Panchet & 600 & Coarse red-yellow-grey soft mica false bedded sst with thick clay \\
\hline Upper Permian & Raniganj & 1050 & Fine to medium grained grey and greenish sst, shales and coal seams \\
\hline Middle Permian & Barren measures & 550 & Carb. Shale with bands of sandy mica shales and clay iron stone \\
\hline Lower Permian & Barakar & 650 & Coarse white and grey sst, conglomerate shales and coal seams \\
\hline Upper Carboniferous & Talchir & 300 & $\begin{array}{l}\text { Coarse sst, white-variegated green shales and fine grained sst } \\
\text { with undecomposed feldspar and boulder beds at the base }\end{array}$ \\
\hline \multicolumn{4}{|l|}{ Unconformity } \\
\hline Archaeans & & & Granites, gneisses and schists \\
\hline
\end{tabular}

Essar is producing $>1$ lakh $\mathrm{m}^{3}$ of gas from 25 wells, and GEECL is producing $>2.5$ lakh m $\mathrm{m}^{3}$ of gas from 40 wells along with large quantity of water at $10 \mathrm{~m}^{3}$ per well per day. The location of produced water samples from CBM wells and mines is marked in Fig. 3.

\section{Methods and experiments}

Produced water samples were collected from five CBM production wells and five coal mine water disposal heads in Raniganj Coalfield. The standard methods for examination of water and wastewater suggested by APHA.AWWA.WPCF (1992) were used for analysis of water samples drawn from CBM wells and coal mine heads. The water samples were kept in dry place under normal atmospheric temperature and then analysed for $\mathrm{pH}$, electrical conductivity and turbidity. The water samples were filtered and divided into two halves. Half samples were acidified to $\mathrm{pH}$ 2.0 with concentric nitric acid $\left(\mathrm{HNO}_{3}\right)$, and other half left as un-acidified. The un-acidified samples were analysed for anions such as $\mathrm{SO}_{4}{ }^{2-}, \mathrm{Cl}^{-}, \mathrm{F}^{-}$and $\mathrm{NO}_{3}{ }^{-}$using ion chromatography (IC) and for cations $\left(\mathrm{Ca}^{2+}, \mathrm{Na}^{+}, \mathrm{Mg}^{2+}\right.$ and $\mathrm{K}^{+}$) by atomic adsorption spectrophotometry (AAS). Acidified water samples were analysed for metals such as $\mathrm{Fe}, \mathrm{Al}, \mathrm{Cr}, \mathrm{Mn}, \mathrm{Pb}, \mathrm{Cu}, \mathrm{As}, \mathrm{Zn}, \mathrm{Se}, \mathrm{Mo}, \mathrm{Cd}, \mathrm{Ba}$ and $\mathrm{B}$ by inductively coupled plasma mass spectrophotometry (ICPMS). Bicarbonate and total alkalinity [phenolphthalein alkalinity (calcium carbonate $\left.\left(\mathrm{CaCO}_{3}{ }^{-}\right)\right)+$methyl orange alkalinity $\left.\left(\mathrm{HCO}_{3}{ }^{-}\right)\right]$on un-acidified samples were 


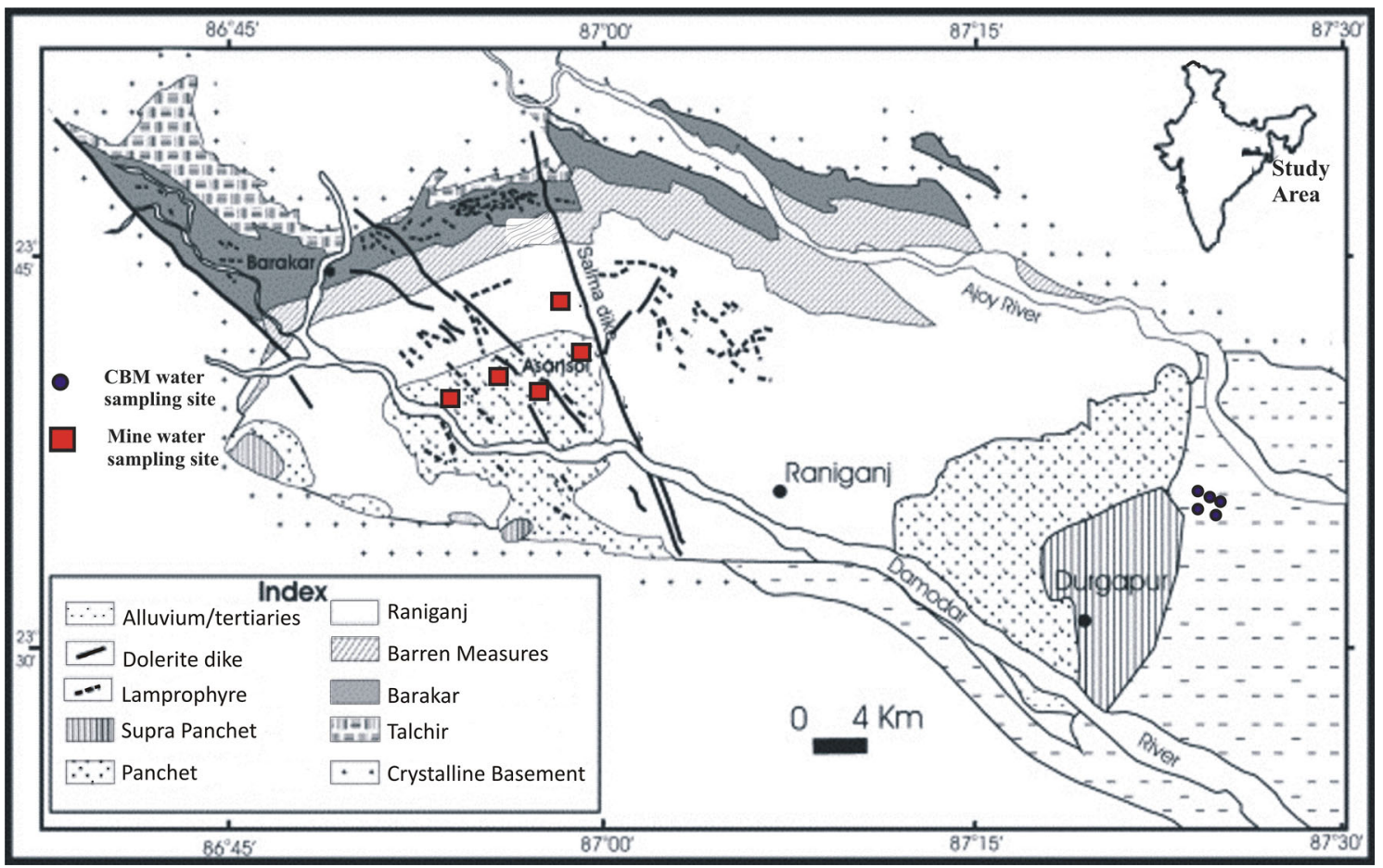

Fig. 3 Location of water samples in Raniganj Coalfield (modified after Gee 1932)

determined by acid titration method. The first is to titrate the water with acid titrant to the phenolphthalein end point. This is called the phenolphthalein alkalinity. Since phenolphthalein changes colour at $\mathrm{pH} \sim 8.3$, this corresponds to a $\mathrm{pH}$ where all the $\mathrm{CO}_{3}{ }^{2-}$ present were protonated. Second, acid titration to a methyl orange end point, $\mathrm{pH}$ $\sim 4.3$, further converts the bicarbonate to aqueous carbon dioxide. At this end point, some of the weaker conjugate bases are protonated. The sum of phenolphthalein alkalinity and methyl orange alkalinity indicates total alkalinity.

\section{Results and discussion}

The results of different analysis of CBM- and mine-produced water samples are given in Table 1 . The $\mathrm{pH}, \mathrm{EC}$, turbidity and TDS values for CBM water vary from 8.260 to $8.720,3090$ to $4600 \mu \mathrm{s} / \mathrm{cm}, 0.600$ to $2.360 \mathrm{NTU}$ and 2070.300 to $3082.000 \mathrm{mg} / \mathrm{L}$, respectively. The $\mathrm{pH}, \mathrm{EC}$, turbidity and TDS values for mine water range from 6.820 to $8.580,623$ to $1513 \mu \mathrm{s} / \mathrm{cm}, 0.740$ to $2.300 \mathrm{NTU}$ and 417.410 to $1013.710 \mathrm{mg} / \mathrm{L}$, respectively.

The mine water of the Raniganj Coalfield is mildly acidic to alkaline in nature, and the variation between CBM and mine water is shown in Fig. 4. CBM-produced water in Raniganj Coalfield typically has rich concentrations of total dissolved solids than coal mine water (Fig. 5). The distribution of major ions and SAR is given in Fig. 6, which shows that bicarbonate and sodium concentration in CBM water are relatively high ranging from $2129.400-2771.300$ to $349.800-976.100 \mathrm{mg} / \mathrm{L}$, respectively, whereas for mine water it varies within values of 132.450-1023.950 and 0.000-297.300 mg/L. Heavy metals have similar range of distribution in both CBM and coal mine water, except manganese concentration is observed relatively high in mine water as shown in Fig. 7. The relationship between TDS and $\mathrm{HCO}^{-}$is presented in Fig. 8. It displays a very good correlation separately for $\mathrm{CBM}$ and mine water. SAR and $\mathrm{Na}^{+}$concentrations vary proportionately to each other (Fig. 9). Ternary diagram showing cations and anions distribution for CBM and mine water is given in Figs. 10 and 11. The stiff plots of cations and anions of CBM and mine water are presented in Figs. 12 and 13. It is observed that CBM water contains wide distribution of $\mathrm{Na}^{+}$and $\mathrm{HCO}_{3}{ }^{-}$, while mine water contains $\mathrm{SO}_{4}{ }^{2-}$ and $\mathrm{HCO}_{3}{ }^{-}$.

Water that is produced from deeper coal formations can contain $\mathrm{NO}_{3}{ }^{-}, \mathrm{Cl}^{-}$, metals and high levels of total dissolved solids, which makes it unsafe for drinking purposes (Jamshidi and Jessen 2012). The mine water can be used for domestic uses after proper treatment and disinfection. Sulphate is usually derived from the weathering of sulphide-bearing minerals like pyrite $\left(\mathrm{FeS}_{2}\right)$, or dissolution of gypsum $\left(\mathrm{CaSO}_{4} \cdot 2 \mathrm{H}_{2} \mathrm{O}\right)$ or anhydrite $\left(\mathrm{CaSO}_{4}\right)$. Pyrite $\left(\mathrm{FeS}_{2}\right)$ occurs as a secondary mineral in the Gondwana 
Table 1 Physical and chemical properties of CBM and mine water samples

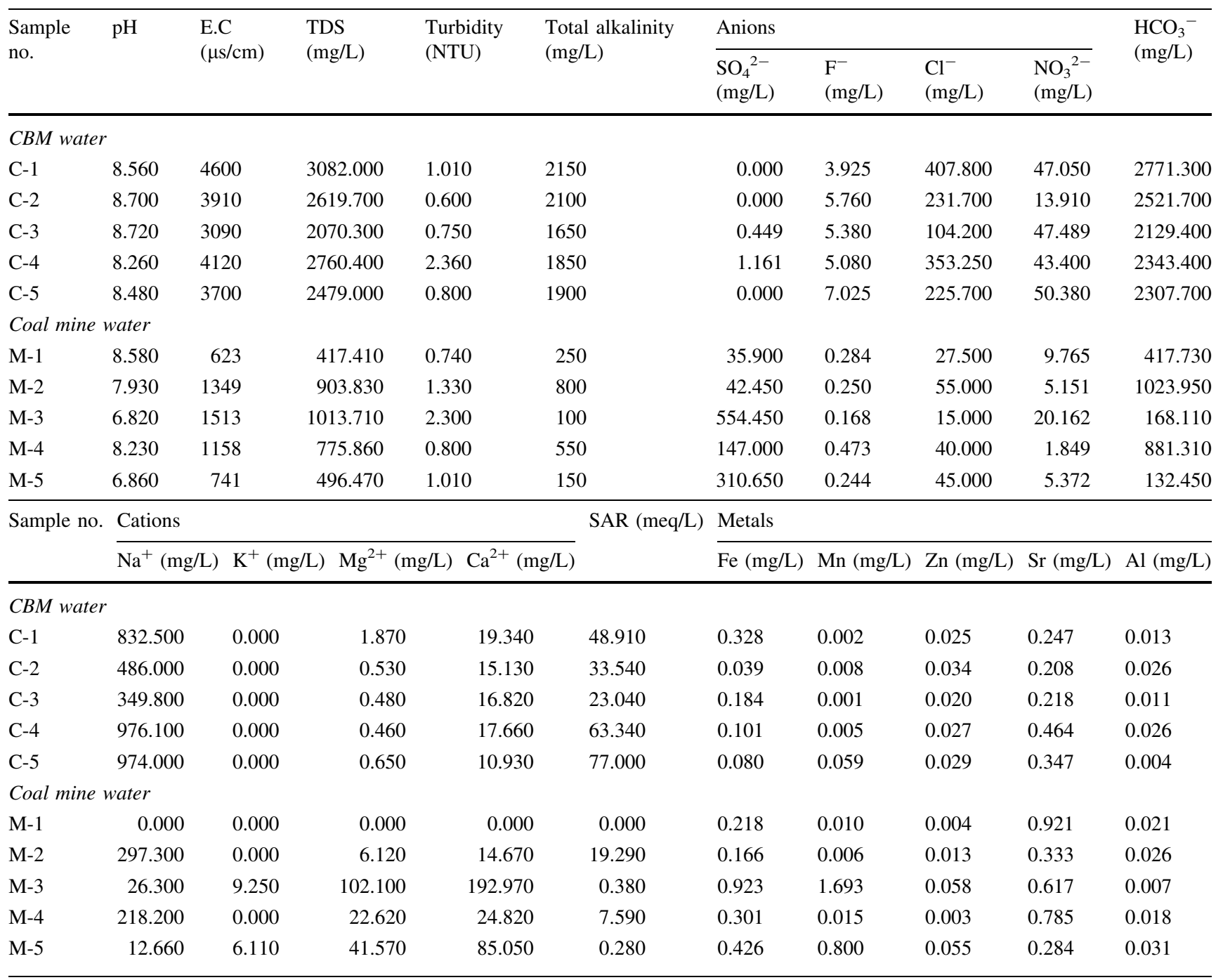

Fig. 4 Variation in $\mathrm{pH}$ of $\mathrm{CBM}$ and mine water

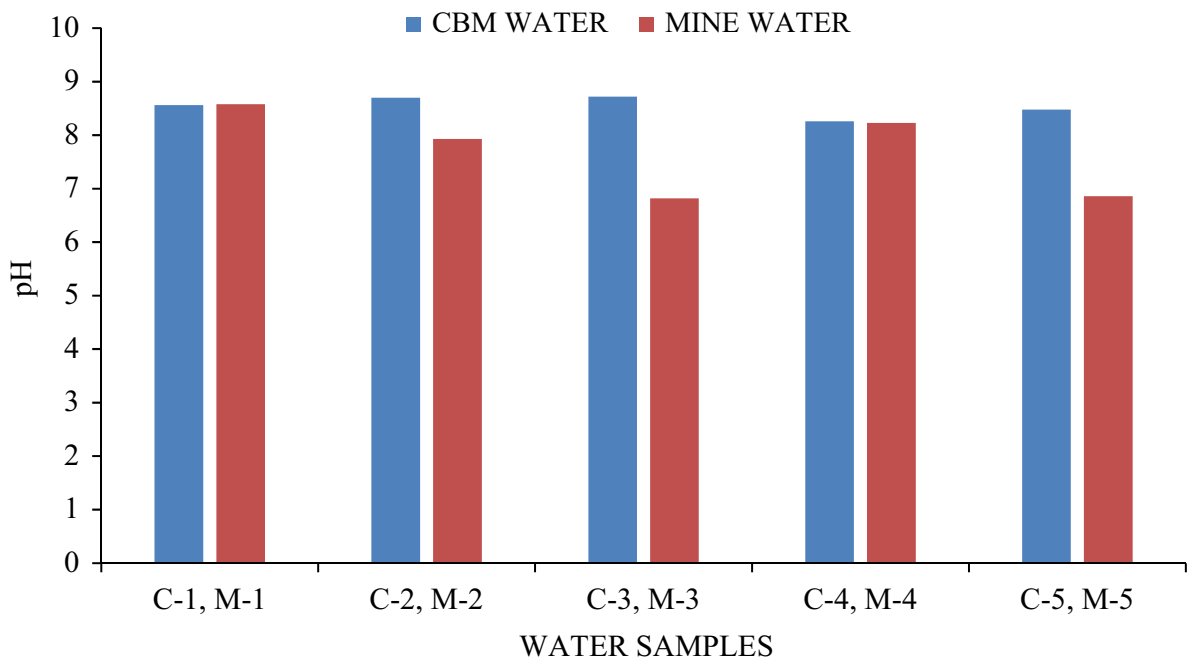


Fig. 5 Variation in TDS

concentration of CBM and mine water

Fig. 6 Variation of major ions and SAR in CBM and mine water

Fig. 7 Variation of trace metals in $\mathrm{CBM}$ and mine water
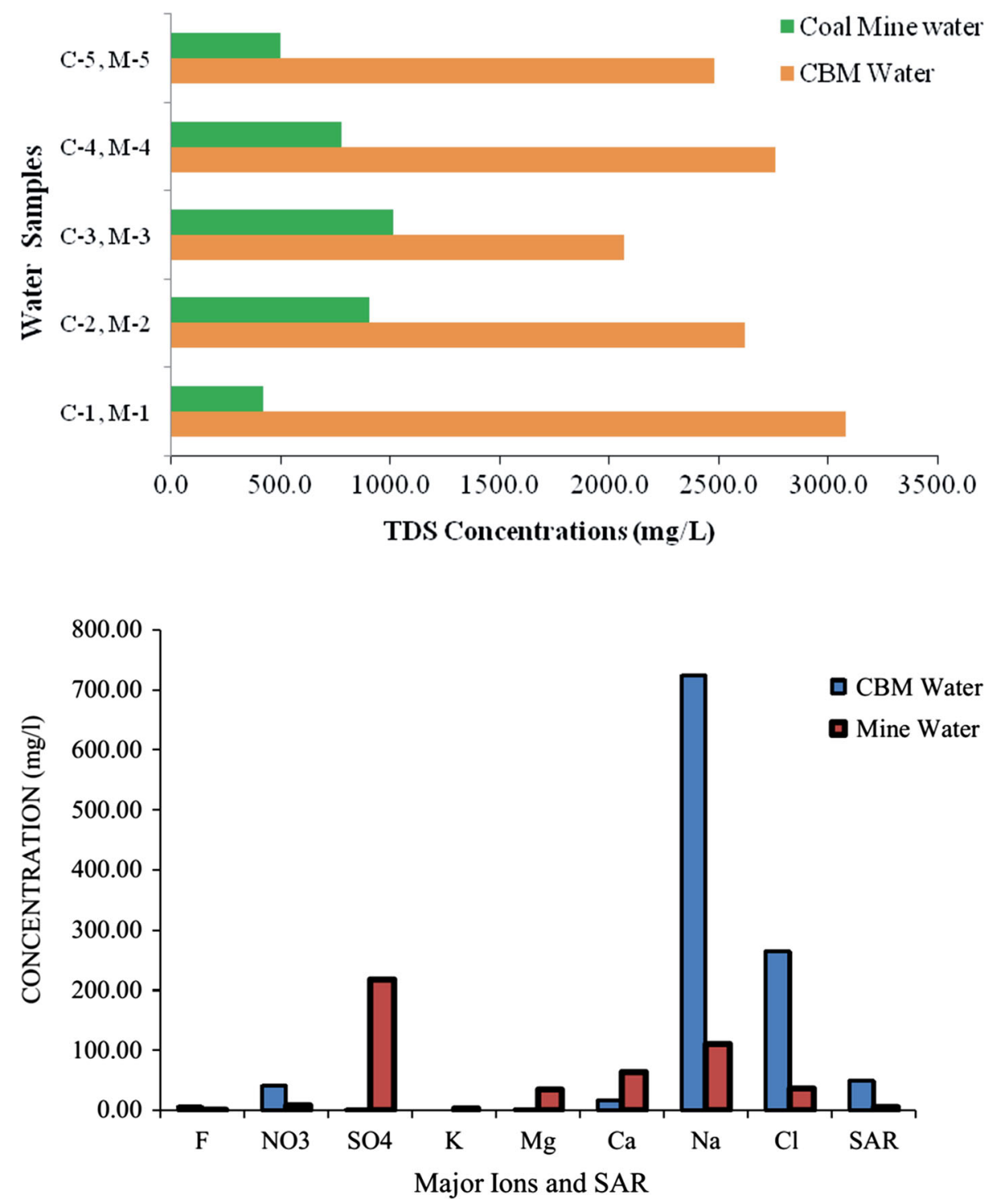

Trace Metals

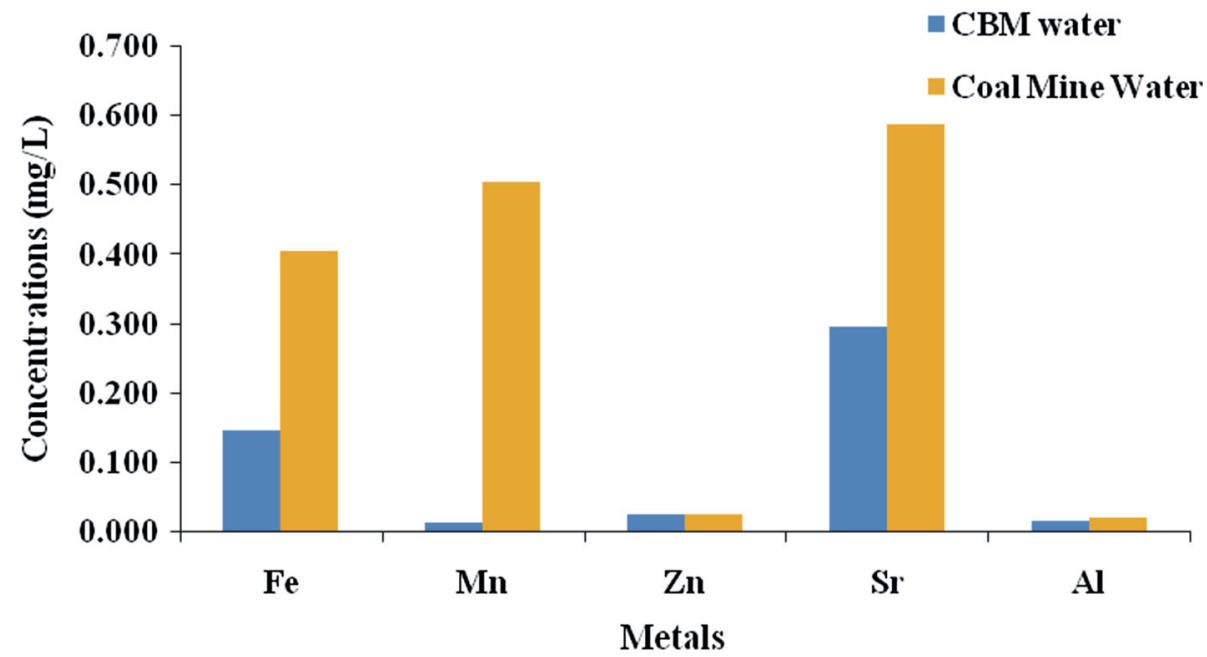




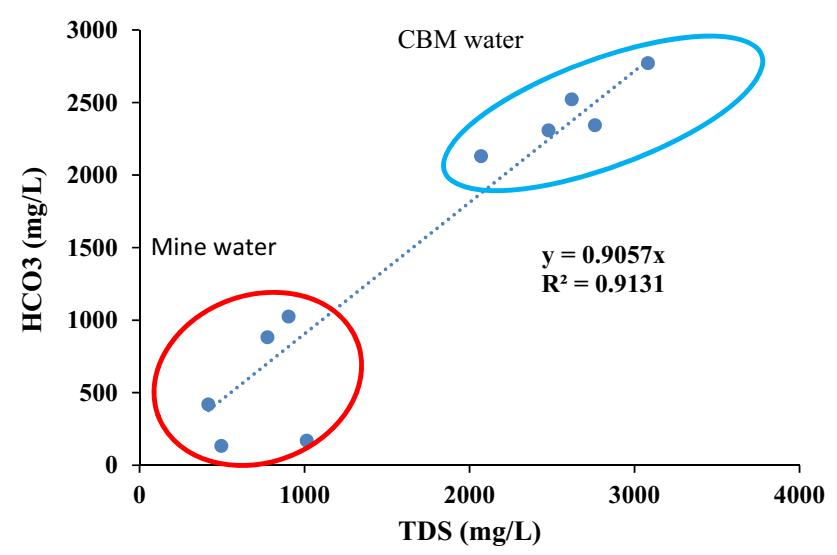

Fig. 8 TDS versus $\mathrm{HCO}_{3}$ of $\mathrm{CBM}$ and mine water

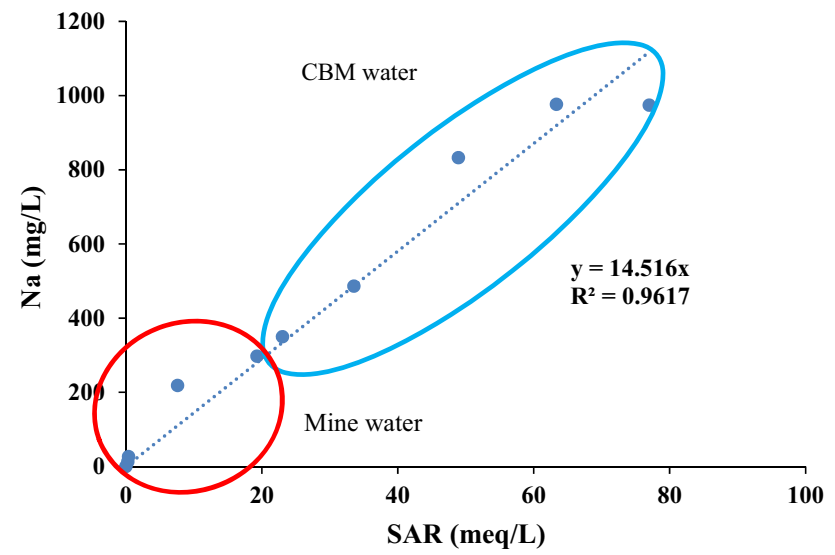

Fig. 9 SAR versus Na of CBM and mine water

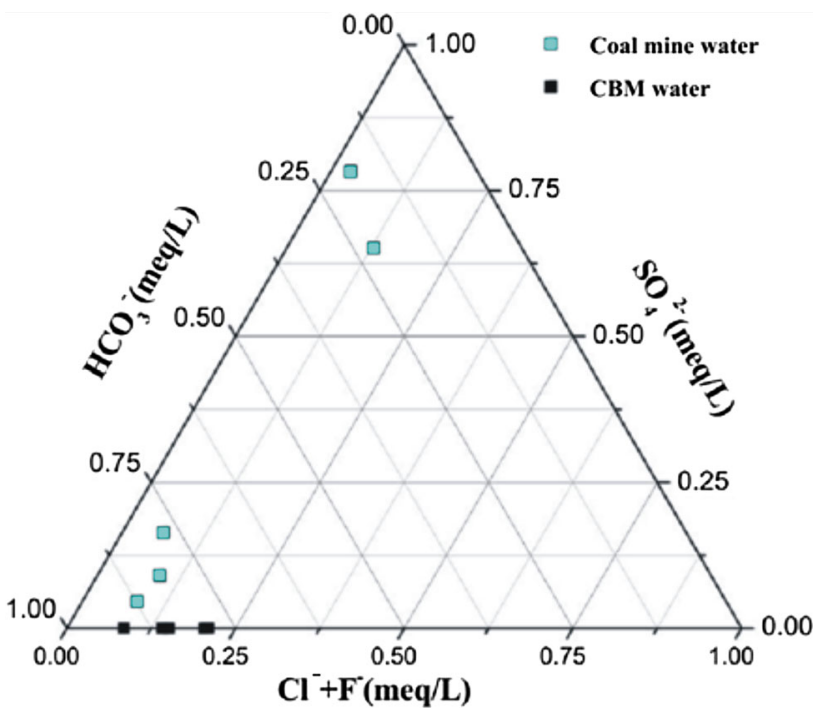

Fig. 10 Ternary diagram for anions of CBM and mine water

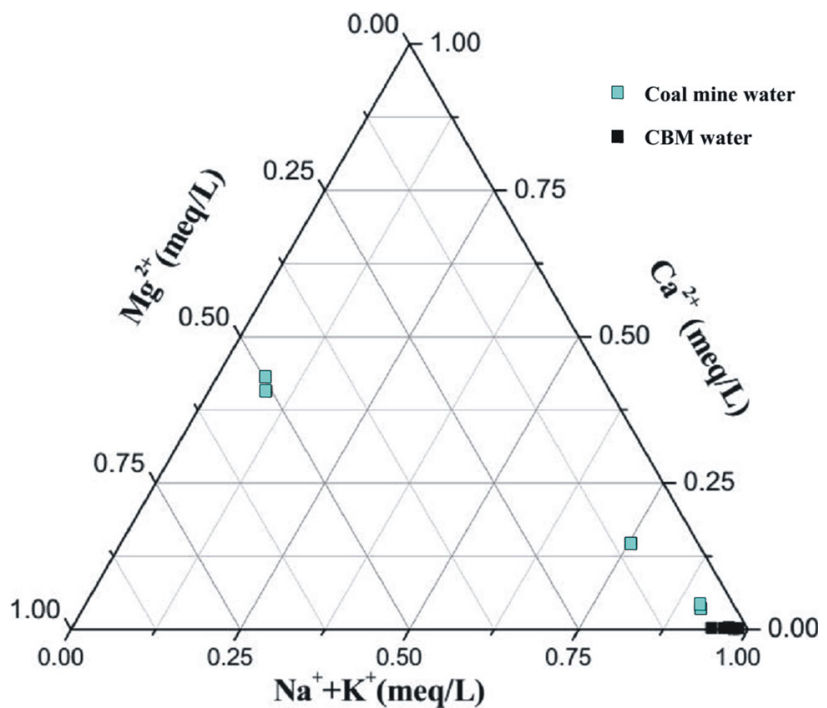

Fig. 11 Ternary diagram for cations of CBM and mine water

coals and associated sediments. The surface disposal and agriculture use of CBM-produced water are restricted due to high values of SAR

$$
\left(\mathrm{SAR}=\frac{\mathrm{Na}^{+}}{\sqrt{\frac{1}{2}\left(\mathrm{Ca}^{2+}+\mathrm{Mg}^{2+}\right)}}\right) \text {, }
$$

which may cause infiltration, surface crusting and also reduces the permeability of soil (Van Voast 2003).

\section{CBM-produced water disposal options}

Management of large volumes of associated water with $\mathrm{CBM}$ production is a potential concern due to the presence of elevated water salinity and sodicity. The produced water is managed in different ways in different areas of the USA and other countries. Existing production in the Powder River Basin utilizes a variety of options to manage CBMproduced water. Deep injection, aquifer storage, surface water discharge, land application (irrigation with amendments), livestock watering and impoundment are all being used to manage produced water. Land application of the CBM-associated high saline-sodic water is a common management method that has been practiced in the Powder River Basin of Wyoming and Montana. The agricultural use of the co-produced waters from CBM is another management option. However, the use of produced water for irrigation can result in deterioration in soil quality and 
Fig. 12 Stiff diagram for CBM water (sample C-2)

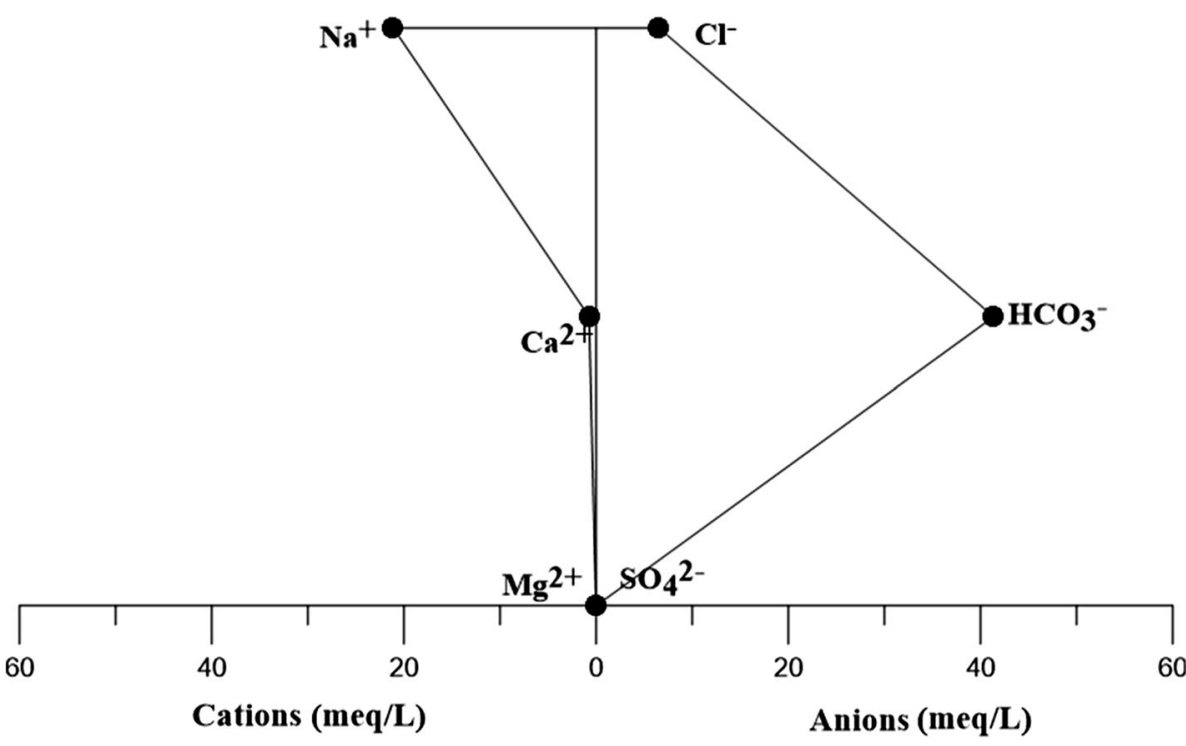

Fig. 13 Stiff diagram for coal mine water (sample M-1)

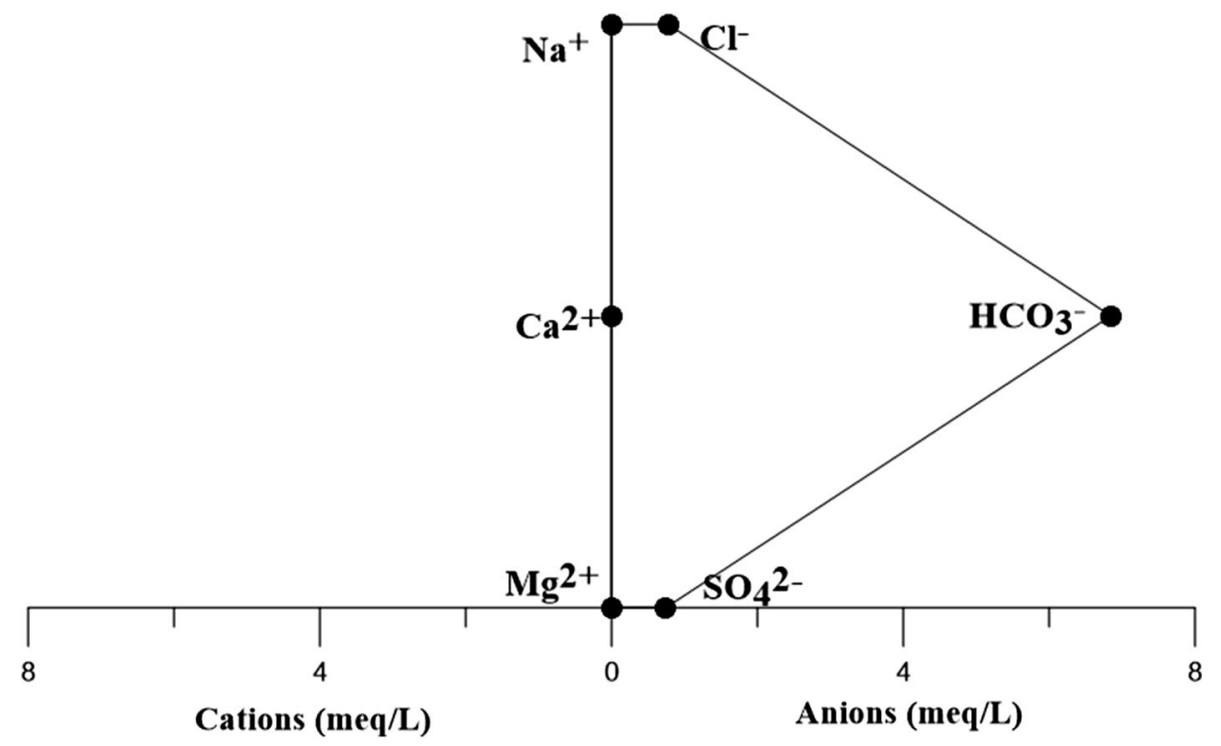

changes in physical and chemical parameters of the soil (Veil and Clark 2011).

Considering the quality and quantity of produced water, following options may be useful for appropriate use and disposal of CBM water in Raniganj Coalfield. Irrigation may be a suitable option for CBM-produced water only after desalinization and proper treatment. Irrigation has several critical aspects which need to be taken care for proper balance of soil quality and crops grown in the area. Impounding CBM water by pumping it into storage facilities, reservoirs and ponds has traditionally been a preferred water management option for CBM operators and may be one of the effective methods in Raniganj Coalfield. These impoundments are well known as infiltration ponds, evaporation ponds, or zero-discharge ponds. Drinking water availability is the major issue in Raniganj Coalfield. The large quantity of water generated from CBM production wells can be potential freshwater sources for various applications, including potable consumption. These challenges include high treatment cost, potential chronic toxicity of the treated produced water and public acceptance. Because of the need of desalination and removal of a large number of chemical compounds, RO will most likely be used for potable reuse applications. It is emphasized that the main challenges present in produced water are desalination, degassing, suspended solids removal, organic compounds removal, heavy metal and others. Achieving the various treatment goals requires the use of multiple treatment technologies, including physical, chemical, and biological treatment processes (Ahmadun et al. 2009). 
Some of the technologies are removal of TDS by precipitation, electrochemical or photocatalytic oxidation, nanofiltration or reverse osmosis, removal of metal through aeration, settling, sand filtration with suspended solids removal, coagulation/flocculation, sedimentation and filtration. The surface discharge and sub-surface injection of the produced water should be treated up to the requirements of the locals and state regulatory limitations for discharge and injection.

\section{Conclusions}

The appraisal of CBM- and mine-produced water is useful for evaluating water quality from different geological formations, which normally have distinctly different geochemical signatures. Coal mine water is relatively higher in dissolved calcium $\left(\mathrm{Ca}^{2+}\right)$, magnesium $\left(\mathrm{Mg}^{2+}\right)$, chloride $\left(\mathrm{Cl}^{-}\right)$and sulphate $\left(\mathrm{SO}_{4}{ }^{2-}\right)$, whereas water from the deep coalbeds associated with adsorbed methane gas is comparatively higher in dissolved sodium $\left(\mathrm{Na}^{+}\right)$and bicarbonate $\left(\mathrm{HCO}_{3}{ }^{-}\right)$. The $\mathrm{CBM}$ water is categorized as $\mathrm{Na}-\mathrm{K}$ type, $\mathrm{Na}-\mathrm{HCO}_{3}$ type and $\mathrm{HCO}_{3}$ type, whereas the coal mine water may be categorized as the $\mathrm{Ca}-\mathrm{Mg}-\mathrm{HCO}_{3}$, $\mathrm{HCO}_{3}-\mathrm{Cl}-\mathrm{SO}_{4}$ and $\mathrm{Na}-\mathrm{HCO}_{3}$ type in Raniganj Coalfield. The relevant options for management and surface/subsurface disposal of large volume of produced water from CBM wells are impounding, irrigation and drinking water on the basis of water $\mathrm{pH}, \mathrm{EC}$, TDS, alkalinity, bicarbonate, sodium, fluoride, metals content and SAR values. The effective management of CBM and coal mine water in Raniganj Coalfield required more specific scientific investigation before adoption of any disposal method.

Acknowledgments The authors are grateful to the Director CIMFR for granting permission to carry out different analysis and publication of this paper.

Open Access This article is distributed under the terms of the Creative Commons Attribution 4.0 International License (http:// creativecommons.org/licenses/by/4.0/), which permits unrestricted use, distribution, and reproduction in any medium, provided you give appropriate credit to the original author(s) and the source, provide a link to the Creative Commons license, and indicate if changes were made.

\section{References}

Ahmadun FL, Pendashteh A, Abdullah LC, Biak DRA, Madaeni SS, Abidin ZZ (2009) Review of technologies for oil and gas produced water treatment. J Hazard Mater 170:530-551

ALL (2003) Handbook on coal bed methane produced water: management and beneficial use alternatives. Prepared by ALL Consulting for the Ground Water Protection Research Foundation, U.S. Department of Energy, and U.S. Bureau of Land Management

APHA.AWWA.WPCF (1992) Standard methods for the examination of water and waste water, 16th edn. APHA, Washington

Breit G, Klett TR, Rice CA, Ferderer DA, Kharaka Y (1998) National compilation of information about water co-produced with oil and gas. In: 5th international petroleum environmental conference, Albuquerque, NM, Oct 20-23

Coal bed Methane (2013) Dart Energy International. http://www. dartgas.com/

Datta D (2003) Coal resources of West Bengal. Bulletin of the Geological Survey of India, Series 'A', No. 45, Coalfields of India, Volume $\mathrm{V}$

DGH (2006) Directorate General of Hydrocarbons Annual Report "Exploration and Production Activities in India" Ministry of Petroleum, Govt. of India, pp 1-76

Ghosh SC (2002) The raniganj coalfield: an example of an Indian Gondwana rift. Sed Geol 147:155-176

Jackson L, Myers J (2002) Alternative use of produced water in aquaculture and hydroponic systems at Naval Petroleum Reserve No. 3. In: Ground Water Protection Council produced water conference, Colorado Springs, CO, Oct 16-17

Jamshidi M, Jessen K (2012) Water production in enhanced coalbed methane operations. J Petrol Sci Eng 92-93:56-64

Khatib Z, Verbeek P (2003) Water to value-produced water management for sustainable field development of mature and green fields. J Pet Technol 55(1):26-28

Mendhe VA, Mishra P, Varade AM (2010) Coal seam reservoir characteristics for Coalbed Methane in North and South Karanpura Coalfields, Jharkhand, sedimentary basins of India: recent developments. Gondwana Geol Mag 12(2010):141-152

Murthy S, Chakraborti B, Roy MD (2010) Palynodating of subsurface sediments, Raniganj Coalfield, Damodar Basin, West Bengal. J Earth Syst Sci 119(5):701-710

Reddy KJ, McBeth I, Skinner QD (2003) Chemistry of trace elements in coalbed methane product water. Water Res 37:884-890

Shramko A, Palmgren T, Gallo D, Dixit R, Swaco M-I (2009) Analytical characterization of flow-back waters in the field. In: 16th annual petroleum \& biofuels environmental conference (IPEC), Houston, November 3-5 2009

Van Voast WA (2003) Geochemical signature of formation waters associated with coalbed methane. AAPG Bull 87:667-676

Veil J, Clark CE (2011) Produced-water-volume estimates and management practices. SPE Prod Oper 26(3):234-239 